\title{
Endostar inhibits hypoxia-induced cell proliferation and migration via the hypoxia-inducible factor-1 $\alpha /$ vascular endothelial growth factor pathway in vitro
}

\author{
KANA LIN ${ }^{1}$, PANPAN YE ${ }^{2}$, JIAN LIU ${ }^{2}$, FENGYING $\mathrm{HE}^{2}$ and WEN XU ${ }^{2}$ \\ ${ }^{1}$ Department of Clinical Pharmacology, The Second Affiliated Hospital (Binjiang Branch), School of Medicine, \\ Zhejiang University, Hangzhou, Zhejiang 310052; ${ }^{2}$ Eye Center, The Second Affiliated \\ Hospital, Zhejiang University, Hangzhou, Zhejiang 310009, P.R. China
}

Received July 29, 2013; Accepted June 2, 2014

DOI: $10.3892 / \mathrm{mmr} .2014 .3131$

\begin{abstract}
Endostar, a recombinant human endostatin, is recognized as one of the most effective angiogenesis inhibitors. The angiogenesis inhibitory effects of Endostar suggest a possible beneficial role of Endostar in choroidal neovascularization (CNV), which is predominantly induced by hypoxia. In our previous study, it was reported that Endostar may inhibit the proliferation and migration of $\mathrm{RF} / 6 \mathrm{~A}$ choroid-retinal endothelial cells. However, the inhibitory effect of Endostar on hypoxia-induced cell proliferation and migration in RF/6A cells has not yet been elucidated. Therefore, the present study investigated the effect of Endostar on hypoxia-induced cell proliferation and migration in RF/6A cells and the possible mechanisms underlying this effect. Under chemical hypoxia conditions, cell viability was increased to $114.9 \pm 10.1$ and $123.6 \pm 9.6 \%$ in cells treated with 100 and $200 \mu \mathrm{m} \mathrm{CoCl}_{2}$, respectively, compared with the control $(\mathrm{P}<0.01)$. Pretreatment with $10-100 \mu \mathrm{g} / \mathrm{ml}$ Endostar significantly inhibited $\mathrm{CoCl}_{2}$-induced cell proliferation $(\mathrm{P}<0.05)$, and pre-treatment with $10 \mu \mathrm{g} / \mathrm{ml}$ Endostar for 24, 48 and $96 \mathrm{~h}$ attenuated $\mathrm{CoCl}_{2}$-promoted cell migration by $60.5,48.3$ and $39.6 \%$, respectively, compared with the control $(\mathrm{P}<0.001)$. In addition, pretreatment with $10 \mu \mathrm{g} / \mathrm{ml}$ Endostar reversed the cell cycle arrest at $\mathrm{S}$ phase and the increased expression of hypoxia-inducible factor- $1 \alpha$ (HIF-1 $\alpha)$ and vascular endothelial growth factor (VEGF) mRNA in RF/6A cells treated with $200 \mu \mathrm{M} \mathrm{CoCl}_{2}$. These data indicate that Endostar inhibited $\mathrm{CoCl}_{2}$-induced hypoxic proliferation and migration, and limited cell cycle progression in vitro possibly through the HIF-1 $\alpha$ /VEGF pathway.
\end{abstract}

Correspondence to: $\mathrm{Dr}$ Wen Xu, Eye Center, The Second Affiliated Hospital, Zhejiang University, 88 Jiefang Road, Hangzhou, Zhejiang 310009, P.R. China

E-mail: xuwenhz2002@aliyun.com

Key words: endostatin, hypoxia, neovascularization, choroid-retinal endothelial cells

\section{Introduction}

Angiogenesis is a complex process involving angiogenic factor secretion, proteolytic enzyme secretion and activation, extracellular matrix degradation, endothelial cell activation, migration, proliferation, growth, sprouting and lumen formation, new vessel differentiation and maturation, and vasoganglion remodeling (1). Choroidal neovascularization (CNV) is one of the most important intraocular neovascular manifestations and is correlated with numerous ocular diseases, including age-related macular degeneration (AMD), which is the primary cause of vision loss among people $>60$ years of age in developed countries $(2,3)$, as well as idiopathic chorioretinitis, ocular histoplasmosis, high myopia macular degeneration, ophthalmic tumors and ocular injury.

$\mathrm{CNV}$ is caused by fibrous vascular tissue formed by choroidal neovascular buds passing through the Bruch's membrane and proliferating in the subretinal space (4). The mechanisms underlying CNV are diverse and complex, involving numerous cellular factors and signal transduction pathways that regulate the incidence and development of CNV. Hypoxia-inducible factor (HIF), angiopoietin (Ang) and numerous cytokines, including vascular endothelial growth factor (VEGF), have been found to have an important role in CNV (2,5). Several recent studies found that hypoxia/ischemia has an important role in CNV, and HIF-1 $\alpha$ and VEGF are key regulators of $\mathrm{CNV}$ under hypoxic conditions $(6,7)$.

Recently, an angiogenesis inhibitor has been developed as a novel strategy for the treatment of CNV (8). Endostatin, a $20 \mathrm{kD}$ potential angiogenesis inhibitor, has been found to exert powerful effects preventing endothelial vascular formation and tumor development in vitro and in vivo, mainly in advanced solid tumors and human umbilical vein endothelial cells $(9,10)$. Furthermore, Mori et al (11) compared the similarities between tumor angiogenesis and $\mathrm{CNV}$, and found that endostatins inhibit occular neovascularization, and that the occurrence and development of CNV were negatively correlated with the serum endostatin level. In addition, they also confirmed that systemic application of endostatin inhibited intraocular neovascularization. Tatar et al (12) found that endostatin was expressed in $92 \%$ of CNV samples obtained 
from patients with AMD using immunohistochemical analysis. Our previous study reported that Endostar was able to inhibit cell proliferation and migration in normal $\mathrm{RF} / 6 \mathrm{~A}$ choroid-retinal endothelial cells through regulating the expression of growth factors and inflammatory factors in a dose- and time-dependent manner (13). Although Endostar may effectively inhibit angiogenesis and tumor growth, its specific role and mechanism in regulating $\mathrm{CNV}$ inhibition have not been well defined. In the present study, RF/6A cells were cultured under hypoxic conditions to simulate vascular endothelial cell growth, proliferation and migration in vitro, and were used to examine the possible mechanisms underlying the inhibitory effects of Endostar on cell proliferation and migration.

\section{Materials and methods}

Cell viability assay. RF/6A rhesus choroid retinal endothelial cells obtained from the Institute of Cell Biology, Chinese Academy of Sciences (Shanghai, China) were cultured in Eagle's minimum essential medium (EMEM; Gibco-BRL, Grand Island, NY, USA) supplemented with $10 \%$ fetal bovine serum (FBS; Hangzhou Sijiqing Bioengineering Material Co., Ltd., Hangzhou, China). Hypoxia was induced by exposing the cells to $\mathrm{CoCl}_{2}$ (Sigma-Aldrich, St. Louis, MO, USA) at various concentrations (100-800 $\mu \mathrm{M})$ in EMEM medium with $0.5 \%$ FBS for $24 \mathrm{~h}$, and the cell viability was determined by a methylthiazol tetrazolium (MTT) assay (Sigma-Aldrich). The absorbance at $570 \mathrm{~nm}$ was measured with a Benchmark microplate reader (Bio-Rad, Hercules, CA, USA). The data were reported as percentages of the absorbance in the control cells.

Wound-healing assay. When the cells had been cultured to a monolayer, the cells were wounded with $200 \mu$ l plastic pipette tips and incubated in EMEM containing 0.5\% FBS and $200 \mu \mathrm{M} \mathrm{CoCl}_{2}$, in the absence or presence of Endostar $(0.5,1$ or $10 \mu \mathrm{g} / \mathrm{ml}$; Simcere Pharmaceutical Group, Nanjing, China). Images were captured at 0, 24, 48 and $96 \mathrm{~h}$ using an Olympus IX-81 inverted microscope (Olympus Corp., Tokyo, Japan). Migration was quantified by counting the number of cells that had advanced into the cell-free space from the initial wound border at $0 \mathrm{~h}$.

Cell cycle analysis. Following treatment, the cells were washed with ice-cold phopshate-buffered saline (PBS), trypsinized, resuspended in PBS supplemented with $0.2 \%$ Triton X-100 and $1 \mathrm{mg} / \mathrm{ml}$ RNase A (Sigma-Aldrich), and incubated with propidium iodide (PI; Sigma-Aldrich) for $30 \mathrm{~min}$ at room temperature in the dark for DNA staining. The cells were then analyzed using a flow cytometer (FACSCalibur; Becton Dickinson, San Jose, CA, USA) with cell quest software (Becton Dickinson).

Determination of the levels of secreted VEGF using ELISA. Following overnight serum starvation, the cells in the 24-well culture plates were pretreated with $0,0.5,1$ or $10 \mu \mathrm{g} / \mathrm{ml}$ Endostar, for $1 \mathrm{~h}$ and then treated with $200 \mu \mathrm{M} \mathrm{CoCl}_{2}$ for $24 \mathrm{~h}$. The culture medium $(200 \mu \mathrm{l})$ was collected by centrifugation at $100 \mathrm{x} \mathrm{g}$ for $10 \mathrm{~min}$ and the VEGF content was detected using a commercial human VEGF ELISA kit (R\&D Systems, Minneapolis, MN, USA) according to the manufacturer's instructions and calculated as $\mathrm{pg} / \mathrm{ml}$ protein.

Reverse transcription-polymerase chain reaction (RT-PCR). To identify the mRNA expression levels of HIF-1 $\alpha$ and VEGF, the total RNA was extracted using TRIzol reagent (Invitrogen Life Technologies, Carlsbad, CA, USA) according to the manufacturer's instructions and reverse-transcribed into cDNA in a $20 \mu \mathrm{l}$ reaction, which was incubated at $42^{\circ} \mathrm{C}$ for $60 \mathrm{~min}$, and then heated to $72^{\circ} \mathrm{C}$ for $10 \mathrm{~min}$ to inactivate the reverse transcriptase. cDNA was then used as a template in a $20-\mu 1$ PCR system under the following conditions: Denaturation at $94^{\circ} \mathrm{C}$ for $2 \mathrm{~min}$ followed by 35 cycles of denaturation at $94^{\circ} \mathrm{C}$ for $10 \mathrm{sec}$, annealing at $55^{\circ} \mathrm{C}$ for $10 \mathrm{sec}$ and elongation at $72^{\circ} \mathrm{C}$ for $10 \mathrm{sec}$, and a final incubation at $72^{\circ} \mathrm{C}$ for $10 \mathrm{~min}$. The amplified products were examined on $2 \%$ agarose gels and densitometrically analyzed with a UVP gel analysis system (Bio-Rad). The primer sequences were as follows: Forward: 5'-CAT TAG AAA GCA GTT CCG CAA GC-3' and reverse: 5'-CAG TGG TAG TGG TGG CAT TAG C-3' for human HIF-1 $\alpha$; forward: 5'-GAG CCT TGC CTT GCT GCT CTA C-3' and reverse: 5'-CAC CAG GGT CTC GAT TGG ATG-3' for human VEGF; and forward: 5'-TCA ACG GAT TTG GTC GTA TT-3' and reverse: 5'-CTG TGG TCA TGA GTC CTT CC-3' for human glyceraldehyde-3-phosphate dehydrogenase (GAPDH). The primers were synthesized by Sangon Biotech (Shanghai, China).

Statistical analysis. The data are expressed as the mean \pm standard deviation and were statistically analyzed by one-way analysis of variance using Prism 4 software (GraphPad software Inc., San Diego, CA, USA). P $<0.05$ was considered to indicate a statistically significant difference.

\section{Results}

Induction of hypoxia with $\mathrm{CoCl}_{2}$. Treatment with $\mathrm{CoCl}_{2}$ at doses $<400 \mu \mathrm{M}$ for $24 \mathrm{~h}$ was able to induce cell proliferation , as measured by an MTT assay. The cell viability was $114.9 \pm 10.1$ and $123.6 \pm 9.6 \%$ in cells treated with 100 and $200 \mu \mathrm{M} \mathrm{CoCl}_{2}$, respectively $(\mathrm{P}<0.01)$. However, at a concentration $>400 \mu \mathrm{M}$, $\mathrm{CoCl}_{2}$ significantly inhibited cell proliferation (Fig. 1).

Effect of Endostar on the viability of $\mathrm{CoCl}_{2}$-treated $\mathrm{RF} / 6 \mathrm{~A}$ cells. The viability of RF/6A cells treated with $200 \mu \mathrm{M}$ $\mathrm{CoCl}_{2}$ for $24 \mathrm{~h}$ was significantly increased compared with the untreated control cells. Pre-treatment with Endostar at concentrations of $1-500 \mu \mathrm{g} / \mathrm{ml}$ significantly attenuated $\mathrm{CoCl}_{2}$-induced increase in cell viability $(\mathrm{P}<0.05)$; however, treatment with $500 \mu \mathrm{g} / \mathrm{ml}$ Endostar resulted in a decline in cell viability of RF/6A cells compared with that of the untreated cells (Fig. 2). This therefore suggested that concentrations of Endostar $>100 \mu \mathrm{g} / \mathrm{ml}$ may have toxic effects on these cells.

Effect of Endostar on the migration of $\mathrm{CoCl}_{2}$-treated RF/6A cells. The effect of Endostar on the migration of $\mathrm{CoCl}_{2}$-treated $\mathrm{RF} / 6 \mathrm{~A}$ cells was examined using a wound-healing assay in vitro. It was identified that $\mathrm{CoCl}_{2}$ treatment for $24 \mathrm{~h}$ 


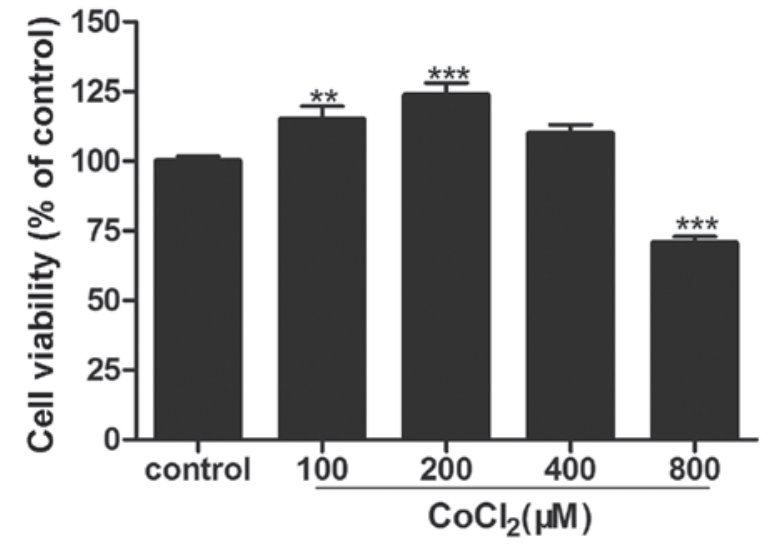

Figure 1. Effect of different concentrations of $\mathrm{CoCl}_{2}$ on choroid-retinal endothelial (RF/6A) cell growth as measured by a methylthiazol tetrazolium assay. The control cells did not receive any treatment. Data are expressed as the mean \pm standard deviation $(n=18) .{ }^{* *} \mathrm{P}<0.01$ and ${ }^{* * * *} \mathrm{P}<0.001$ vs. the control.

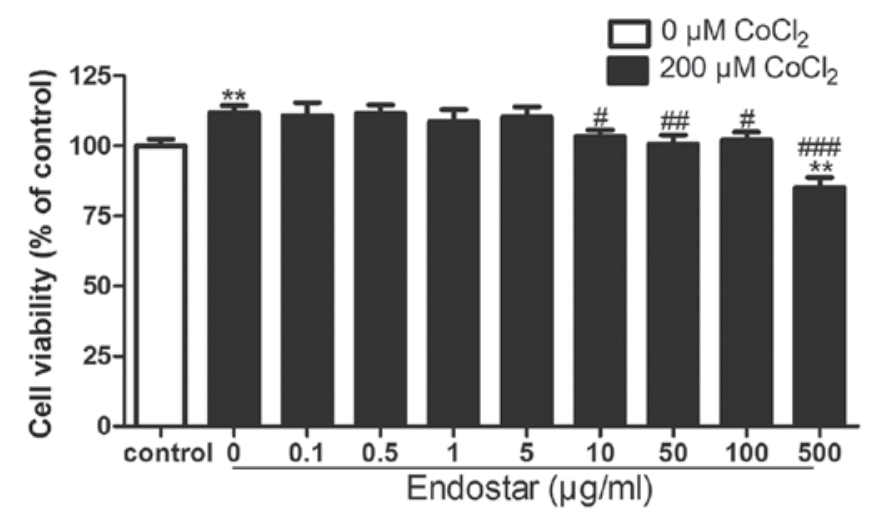

Figure 2. Inhibitory effect of Endostar on $\mathrm{CoCl}_{2}$-induced choroid-retinal endothelial ( $\mathrm{RF} / 6 \mathrm{~A})$ cell proliferation as determined by a methylthiazol tetrazolium assay. The control cells did not receive any treatment. Data are expressed as the mean \pm standard deviation $(\mathrm{n}=18)$. ${ }^{* * * *} \mathrm{P}<0.001$ vs. the control; ${ }^{\#} \mathrm{P}<0.05,{ }^{\# \#} \mathrm{P}<0.01$ and ${ }^{\# \#} \mathrm{P}<0.001$ vs. the cells treated with $\mathrm{CoCl}_{2}$ only.

significantly promoted cell migration, which was inhibited by Endostar pretreatment at different time points (Fig. 3). As shown in Fig. 4, cell migration was inhibited by Endostar treatment in a time and dose-dependent manner. Under hypoxic conditions, the cell migration was increased nearly 2-fold compared with the level in the control group after $24 \mathrm{~h}$, by $92.0 \%$ compared with the control group after $48 \mathrm{~h}$, and by $80.4 \%$ after $72 \mathrm{~h}$. Compared with the group treated with $\mathrm{CoCl}_{2}$ alone, cell migration was decreased to 70.0, 60.9 and $60.5 \%$ following $24 \mathrm{~h}, 67.8,62.9$ and $48.3 \%$ after $48 \mathrm{~h}$, and $65.3,57.1$ and $39.6 \%$ after $72 \mathrm{~h}$, following treatment with $0.5,1$ and $10 \mu \mathrm{g} / \mathrm{ml}$ Endostar, respectively.

Effect of pretreatment with Endostar on the cell cycle of $\mathrm{CoCl}_{2}$-treated RF/6A cells. The DNA content of $\mathrm{CoCl}_{2}$-treated $\mathrm{RF} / 6 \mathrm{~A}$ cells was used for cell cycle analysis. The results demonstrated that $\mathrm{CoCl}_{2}$ arrested the cell cycle at $\mathrm{S}$ phase and Endostar pretreatment was able to reverse this effect (Fig. 5). It was observed that treatment with $200 \mu \mathrm{M} \mathrm{CoCl}_{2}$ increased the percentage of cells in $\mathrm{S}$ phase from $19.1 \pm 0.9$ to $27.8 \pm 1.5 \%$, but decreased the percentage of cells in G0/G1 phase from $73.5 \pm 1.3$ to $62.8 \pm 1.1 \%$. However, pretreatment with $10 \mu \mathrm{g} / \mathrm{ml}$
Endostar completely reversed these effects, and the percentage of cells in $\mathrm{S}$ phase and G0/G1 phase returned to $16.3 \pm 3.5$ and $73.9 \pm 5.8 \%$, respectively.

Effect of pretreatment with Endostar on the expression of HIF-l $\alpha$ and VEGF in CoCl $\mathrm{Cl}_{2}$ treated RF/6A cells. HIF-1 $\alpha$ and VEGF mRNA levels were quantified with RT-PCR, normalized to the internal control GAPDH and compared. Compared with the control group, $200 \mu \mathrm{M} \mathrm{CoCl}_{2}$ treatment induced a 4-fold increase in HIF-1 $\alpha$ expression, which was then attenuated by Endostart in a concetration-dependent manner $(0.5-10 \mu \mathrm{g} / \mathrm{ml})$ (Fig. 6A and B). In addition, $200 \mu \mathrm{M} \mathrm{CoCl}_{2}$ increased VEGF mRNA expression by $50 \%$, which was then downregulated in a concentration-dependent manner following treatment with 0.5-10 $\mu \mathrm{g} / \mathrm{ml}$ Endostar (Fig. 6A and C). Furthermore, the amount of VEGF protein release into the medium was consistent with that of the mRNA expression of VEGF (Fig. 6D).

\section{Discussion}

Hypoxia/ischemia-associated retinopathy and optic neuropathy is the major cause of blindness, central/branch retinal vein occlusion, diabetic retinopathy and retinopathy of prematurity, which appear to always be accompanied with retinal and choroidal neovascularization at advanced stages, causing vitreous hemorrhage, proliferative retinopathy, retinal detachment and severe visual impairment $(14,15)$. RF/6A cells were isolated from the choroid retina of a healthy rhesus fetus and confirmed as endothelial cells by morphology, growth pattern and immunohistochemistry. RF/6A cells, as a choroidal endothelial cell line, were used to investigate the pathogenesis and prevention of $\mathrm{CNV}$-associated diseases and have been proven to be a reliable in vitro model for the formation of $\mathrm{CNV}$. CNV formation is a complex process $(16,17)$, affected by a variety of etiological factors, including hypoxia, which has an important role in angiogenesis (6). In the present study, $\mathrm{CoCl}_{2}$, a chemical reagent used to establish a hypoxia cell model, induced cell proliferation and migration in a certain dose range. The concentration of $200 \mu \mathrm{M} \mathrm{CoCl}_{2}$ was determined to be appropriate for treating $\mathrm{RF} / 6 \mathrm{~A}$ cells and simulating $\mathrm{CNV}$ formation in vitro.

Endostar, a novel recombinant human endostatin, was synthesized in China and approved as an anticancer drug by the State Food and Drug Administration in 2005 (18). Endostar is easier to purify and has more clinical advantages than Endostatin, demonstrating stable physicochemical characteristics and higher water solubility (19). Endostar exhibits anti-angiogenic effects and has been used to treat numerous types of cancer, including non-small lung, breast and gastric cancer (20-22). However, its applications in the field of ocular disease and the possible underlying molecular mechanisms of its effects have not been well investigated.

The present study demonstrated that $\mathrm{CoCl}_{2}$ treatment promoted the proliferation and migration of $\mathrm{RF} / 6 \mathrm{~A}$ cells and arrested more cells in the $\mathrm{S}$ phase, leaving fewer cells in the G0/G1 phase, while pretreatment with Endostar significantly reversed all $\mathrm{CoCl}_{2}$-mediated effects in $\mathrm{RF} / 6 \mathrm{~A}$ cells. This suggested that the effects of Endostar on the proliferation and migration of $\mathrm{CoCl}_{2}$-induced $\mathrm{RF} / 6 \mathrm{~A}$ cells may occur due to the inhibition of $\mathrm{RF} / 6 \mathrm{~A}$ cell transition from $\mathrm{G} 0 / \mathrm{G} 1$ phase to $\mathrm{S}$ phase. 


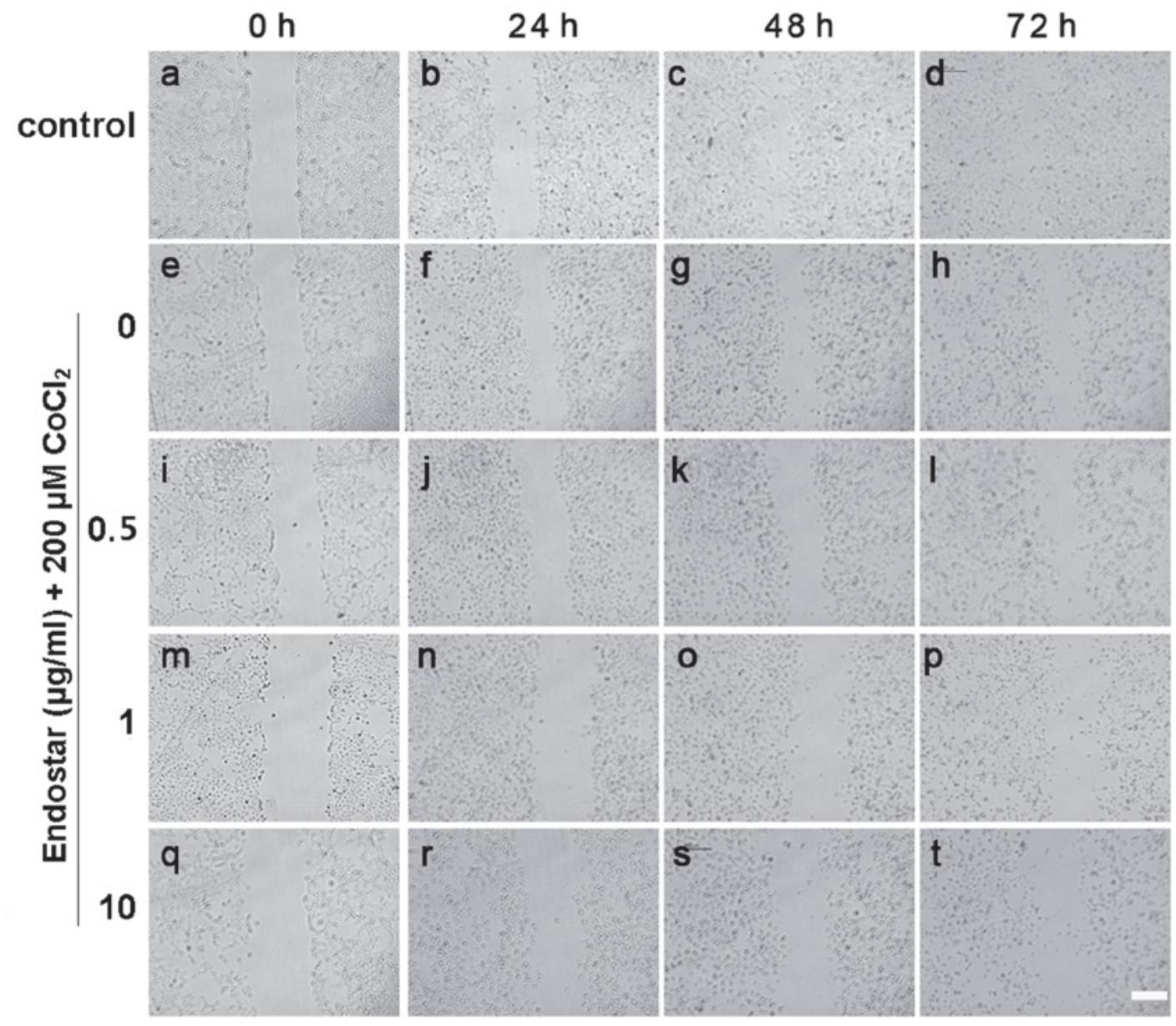

Figure 3. Inhibitory effect of Endostar on the migration of hypoxic choroid-retinal endothelial cells (RF/6A). (a-t) The cells as measured by a wound healing assay in vitro. The migration of cells without any treatment at (a) 0 , (b) 24 , (b) 48 and (d) $72 \mathrm{~h}$; treated with $\mathrm{CoCl}_{2}$ at (e) 0 , (f) 24 , (g) 48 and (h) $72 \mathrm{~h}$; pretreated with $0.5 \mu \mathrm{g} / \mathrm{ml}$ Endostar and treated with $\mathrm{CoCl}_{2}$ at (i) 0 , (j) 24, (k) 48 and (l) $72 \mathrm{~h}$; pretreated with $1 \mu \mathrm{g} / \mathrm{ml}$ Endostar and treated with CoCl ${ }_{2}$ at (m) 0 , (n) 24, (o) 48 and (p) $72 \mathrm{~h}$; pretreated with $10 \mu \mathrm{g} / \mathrm{ml}$ Endostar and treated with $\mathrm{CoCl}_{2}$ at (q) 0, (r) 24, (s) 48 and (t) $72 \mathrm{~h}$. Scale bar, $100 \mu \mathrm{m}$.

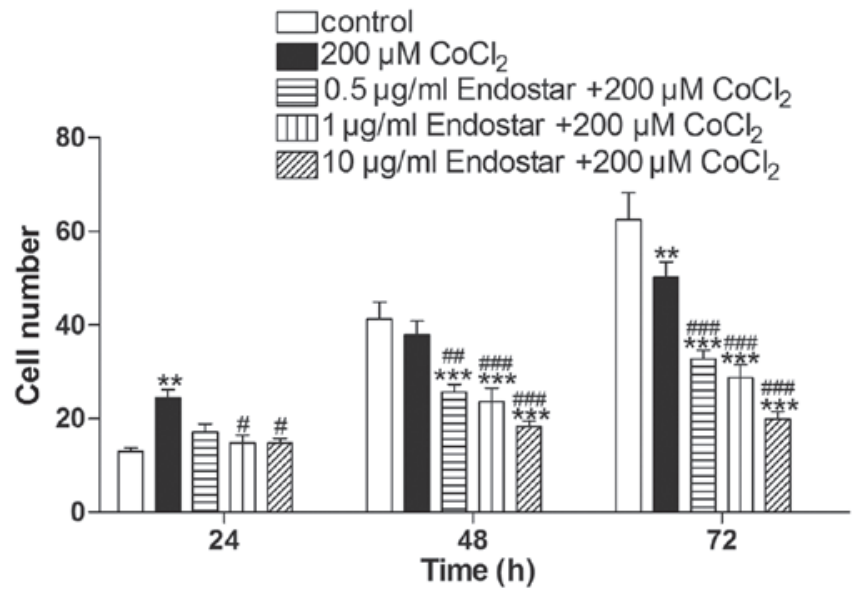

Figure 4. Endostar inhibits $\mathrm{CoCl}_{2}$-induced cell migration. The control cells did not receive any treatment. Data are expressed as the mean \pm standard deviation $(\mathrm{n}=9) .{ }^{* *} \mathrm{P}<0.01$ and ${ }^{* * * *} \mathrm{P}<0.001$ vs. the control at the corresponding time, ${ }^{\#} \mathrm{P}<0.05,{ }^{\# \#} \mathrm{P}<0.01$ and ${ }^{\# \# \#} \mathrm{P}<0.001$ vs. $200 \mu \mathrm{M} \mathrm{CoCl}_{2}$ at the corresponding time.

HIF-1, a DNA binding protein, is an important transcription factor regulating hypoxia (23). It has been found to be overexpressed under hypoxic conditions, implying that hypoxia may increase the content of HIF-1 $\alpha$ to regulate the expression of its downstream genes, including VEGF (7,23-25). In addition, HIF-1 may directly or indirectly regulate the expression of numerous genes, such as VEGF, placental growth factor and TGF- $\beta 1$ (26), in myocardial cells, fibroblasts and smooth muscle cells by binding to its binding site in their promoters (27).

VEGF is a necessary stimulator for retinal and choroidal neovascularization. Numerous agents that bind VEGF or block VEGF receptors may suppress retinal and choroidal neovascularization $(28,29)$. Hypoxia is the main factor leading to $\mathrm{CNV}$, and the subsequent simultaneous increase in VEGF and HIF-1 $\alpha$ expression (30). These studies indicated that hypoxia may enhance the expression of HIF-1 $\alpha$, which subsequently regulates the expression of VEGF. In the present study, it was identified that $\mathrm{CoCl}_{2}$ enhanced the expression of HIF-1 $\alpha$ and VEGF in RF/6A cells in vitro.

Endostatin has been demonstrated to exert anti-angiogenenic effects in a HIF-1 $\alpha$-dependent manner (31). In human lung adenocarcinoma cancer cells, Endostar was able to suppress HIF-1 $\alpha$ and VEGF expression and radiotherapy-induced angiogenesis (32). The present study demonstrated that Endostar inhibited $\mathrm{CoCl}_{2}$-induced HIF-1 $\alpha$ and VEGF expression in RF/6A cells, suggesting that Endostar may affect cell proliferation and migration through regulating the HIF-1 $\alpha$ /VEGF pathway. 
A

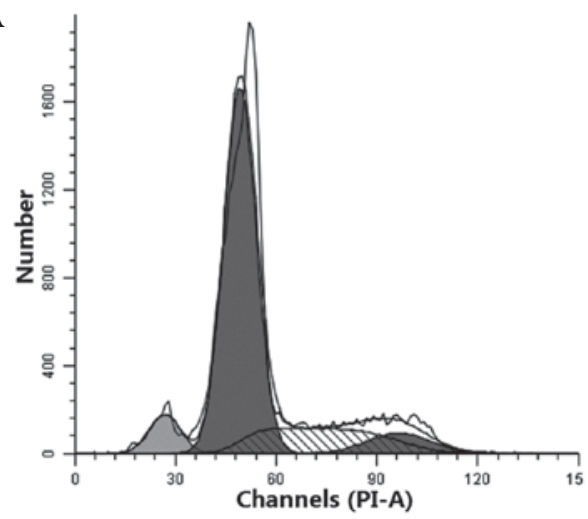

C

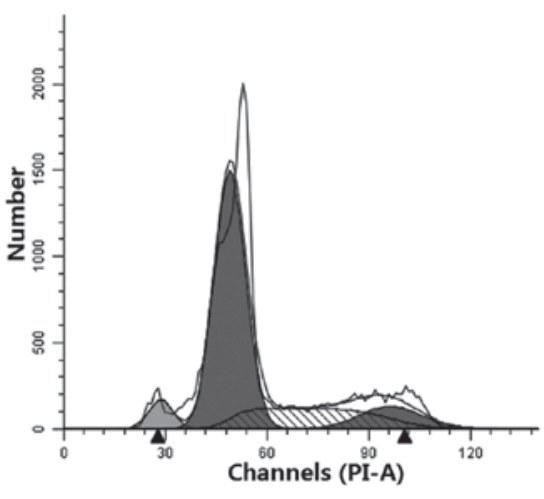

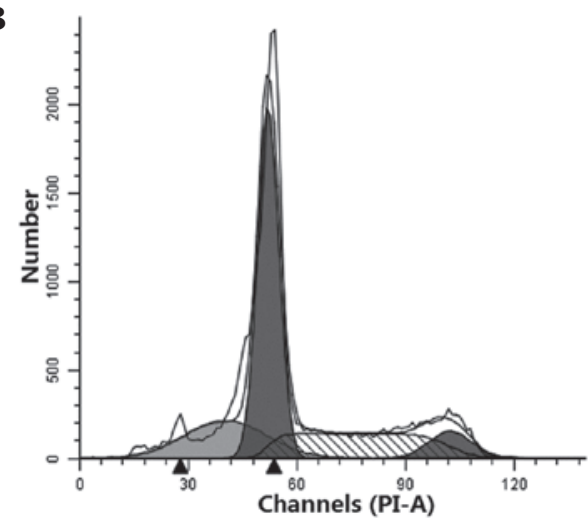

D

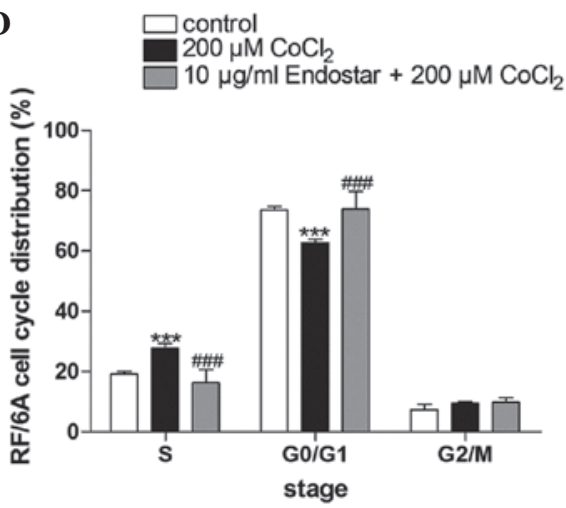

Figure 5. Effect of Endostar on cell cycle progression of hypoxic choroid-retinal endothelial cells (RF/6A) cells. (A) Representative flow cytometric analysis of RF/6A cells without any treatment (control). (B) Representative flow cytometric analysis of RF/6A cells exposed to $200 \mu \mathrm{M} \mathrm{CoCl}$. (C) Representative flow cytometric analysis of RF/6A cells exposed to $200 \mu \mathrm{M} \mathrm{CoCl}_{2}$ following pretreatment with Endostar $(10 \mu \mathrm{g} / \mathrm{ml})$. (D) There was a significant difference in the percentage of cells in S, G0/G1 and G2/M phases among the control cells, $\mathrm{CoCl}_{2}$-treated cells and $\mathrm{CoCl}_{2}$-treated cells following pretreatment with Endostar $(10 \mu \mathrm{g} / \mathrm{ml})$. Data are expressed as the mean \pm standard deviation. ${ }^{* * *} \mathrm{P}<0.001$ vs. the control; ${ }^{\# \# \#} \mathrm{P}<0.001 \mathrm{vs} .200 \mu \mathrm{M} \mathrm{CoCl}_{2}$.

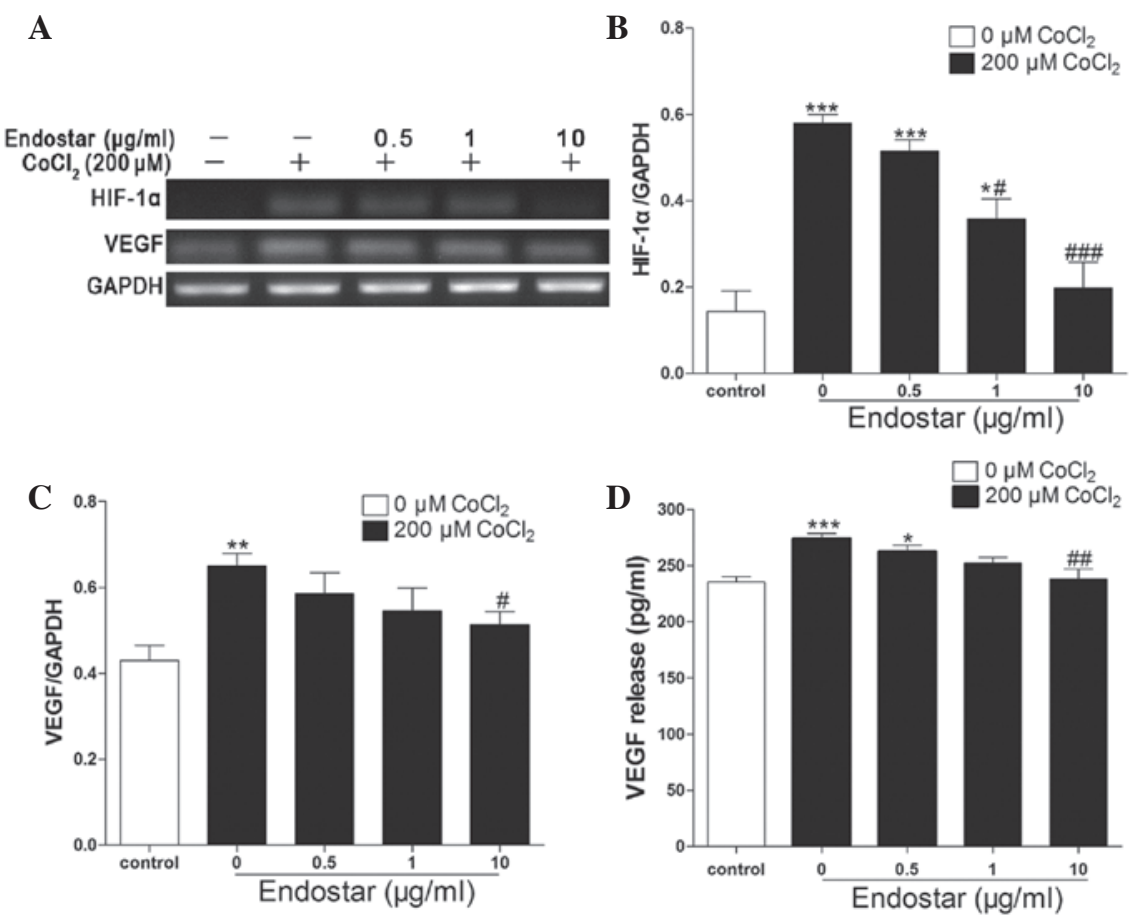

Figure 6. Endostar inhibits HIF-1 $\alpha$ and VEGF expression in hypoxic choroid-retinal endothelial cells (RF/6A). (A) After the cells were incubated for $24 \mathrm{~h}$ with $200 \mu \mathrm{M} \mathrm{CoCl}_{2}$ in the absence or presence of $0.5,1$ and $10 \mu \mathrm{g} / \mathrm{ml}$ Endostar, mRNA levels of HIF-1 $\alpha$ and VEGF were detected by RT-PCR. (B and C) Densitometric analyses of RT-PCR are presented as the mean \pm standard deviation of three independent experiments performed in triplicate. (D) After the cells were treated with $200 \mu \mathrm{M} \mathrm{CoCl}_{2}$ in the absence or presence of Endostar $(0.5,1$, and $10 \mu \mathrm{g} / \mathrm{ml})$, the cell supernatant was used to analyze the secreted

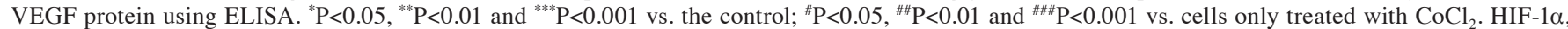
hypoxia-inducible factor $1 \alpha$; VEGF, vascular endothelial growth factor; RT-PCR, reverse transcription-polymerase chain reaction. 
In conclusion, Endostar, a recently introduced recombinant human endostatin, is able to inhibit $\mathrm{CoCl}_{2}$-induced $\mathrm{RF} / 6 \mathrm{~A}$ cell proliferation and migration possibly by downregulating HIF-1 $\alpha$ and secondarily inhibiting VEGF expression. These results indicate that Endostar may have an important role in hypoxia-induced CNV, which highlights its significant potential for clinical application.

\section{Acknowledgements}

This study was supported by the Youth Program of the National Natural Science Foundation of China (grant no. 11104246/A040414); the Zhejiang Natural Science Foundation (grant no. Y2100380); the Zhejiang Science and Technology Department Public Project (grant no. 2010C33085); the Zhejiang Research Foundation of Integrated Traditional Chinese and Western Medicine (grant no. 2012LY013); and the Key Lab Fund of Zhejiang Province (grant no. 2011E10006).

\section{References}

1. Risau W: Mechanisms of angiogenesis. Nature 386: 671-674, 1997.

2. Ambati J, Ambati BK, Yoo SH, Ianchulev S and Adamis AP: Age-related macular degeneration: etiology, pathogenesis, and therapeutic strategies. Surv Ophthalmol 48: 257-293, 2003.

3. Friedman DS, O'Colmain BJ, Munoz B, et al: Prevalence of age-related macular degeneration in the United States. Arch Ophthalmol 122: 564-572, 2004.

4. Bhutto I and Lutty G: Understanding age-related macular degeneration (AMD): relationships between the photoreceptor/retinal pigment epithelium/Bruch's membrane/choriocapillaris complex. Mol Aspects Med 33: 295-317, 2012.

5. Xie P, Zhang W, Yuan S, et al: Suppression of experimental choroidal neovascularization by curcumin in mice. PLoS One 7: e53329, 2012.

6. Yang XM, Wang YS, Zhang J, et al: Role of PI3K/Akt and $\mathrm{MEK} / \mathrm{ERK}$ in mediating hypoxia-induced expression of HIF-1alpha and VEGF in laser-induced rat choroidal neovascularization. Invest Ophthalmol Vis Sci 50: 1873-1879, 2009.

7. Dong X, Wang YS, Dou GR, et al: Influence of DII4 via HIF-1alpha-VEGF signaling on the angiogenesis of choroidal neovascularization under hypoxic conditions. PLoS One 6: e18481, 2011.

8. Kang HM and Koh HJ: Intravitreal anti-vascular endothelial growth factor therapy versus photodynamic therapy for idiopathic choroidal neovascularization. Am J Ophthalmol 155 713-719, 2013.

9. Kim YM, Jang JW, Lee $\mathrm{OH}$, et al: Endostatin inhibits endothelial and tumor cellular invasion by blocking the activation and catalytic activity of matrix metalloproteinase. Cancer Res 60: 5410-5413, 2000.

10. Abdollahi A, Hlatky L and Huber PE: Endostatin: the logic of antiangiogenic therapy. Drug Resist Updat 8: 59-74, 2005.

11. Mori K, Ando A, Gehlbach P, et al: Campochiaro PA. Inhibition of choroidal neovascularization by intravenous injection of adenoviral vectors expressing secretable endostatin. Am J Pathol 159: 313-320, 2001.

12. Tatar O, Shinoda K, Kaiserling E, et al: Early effects of triamcinolone on vascular endothelial growth factor and endostatin in human choroidal neovascularization. Arch Ophthalmol 126: 193-199, 2008
13. Xu W, Ye P, Li Z, Shi J, Wang W and Yao K: Endostar, a recently introduced recombinant human endostatin, inhibits proliferation and migration through regulating growth factors, adhesion factors and inflammatory mediators in choroid-retinal endothelial cells. Mol Biol 44: 664-670, 2010.

14. Neely KA and Gardner TW: Ocular neovascularization: clarifying complex interactions. Am J Pathol 153: 665-670, 1998.

15. Hay WW Jr and Bell EF: Oxygen therapy, oxygen toxicity, and the STOP-ROP trial. Pediatrics 105: 424-425, 2000.

16. Plum SM, Vu HA, Mercer B, Fogler WE and Fortier AH: Generation of a specific immunological response to FGF-2 does not affect wound healing or reproduction. Immunopharmacol Immunotoxicol 26: 29-41, 2004.

17. Chen Y, Li XX, Xing NZ and Cao XG: Quercetin inhibits choroidal and retinal angiogenesis in vitro. Graefes Arch Clin Exp Ophthalmol 246: 373-378, 2008.

18. Ling Y, Yang Y, Lu N, et al: Endostar, a novel recombinant human endostatin, exerts antiangiogenic effect via blocking VEGF-induced tyrosine phosphorylation of KDR/Flk-1 of endothelial cells. Biochem Biophys Res Commun 361: 79-84, 2007.

19. Jiang LP, Zou C, Yuan X, Luo W, Wen Y and Chen Y: N-terminal modification increases the stability of the recombinant human endostatin in vitro. Biotechnol Appl Biochem 54: 113-120, 2009.

20. Lu N, Ling Y, Gao Y, et al: Endostar suppresses invasion through downregulating the expression of matrix metalloproteinase-2/9 in MDA-MB-435 human breast cancer cells. Exp Biol Med 233: 1013-1020, 2008.

21. Wen QL, Meng MB, Yang B, et al: Endostar, a recombined humanized endostatin, enhances the radioresponse for human nasopharyngeal carcinoma and human lung adenocarcinoma xenografts in mice. Cancer Sci 100: 1510-1519, 2009

22. Bong R, Yang S, Li W, Zhang W and Ming Z: Systematic review and meta-analysis of Endostar (rh-endostatin) combined with chemotherapy versus chemotherapy alone for treating advanced non-small cell lung cancer. World J Surg Oncol 10: 170, 2012

23. Covello KL, Simon MC and Keith B: Targeted replacement of hypoxia-inducible factor-1alpha by a hypoxia-inducible factor-2alpha knock-in allele promotes tumor growth. Cancer Res 65: 2277-2286, 2005.

24. Semenza GL: Angiogenesis in ischemic and neoplastic disorders. Annu Rev Med 54: 17-28, 2003.

25. Semenza GL: HIF-1: mediator of physiological and pathophysiological responses to hypoxia. J Appl Physiol 88: 1474-1480, 2000.

26. Kelly BD, Hackett SF, Hirota K, Oshima Y Cai Z, Berg-Dixon S, Rowan A, Yan Z, Campochiaro PA and Semenza GL: Cell type-specific regulation of angiogenic growth factor gene expression and induction of angiogenesis in nonischemic tissue by a constitutively active form of hypoxia-inducible factor 1 . Circ Res 93: 1074-1081, 2003.

27. Lukiw WJ, Ottlecz A, Lambrou G, Grueninger M Finley J, Thompson HW and Bazan NG: Coordinate activation of HIF-1 and NF-kappaB DNA binding and COX-2 and VEGF expression in retinal cells by hypoxia. Invest Ophthalmol Vis Sci 44: 4163-4170, 2003.

28. Berglin L, Sarman S, van der Ploeg I, et al: Reduced choroidal neovascular membrane formation in matrix metalloproteinase-2-deficient mice. Invest Ophthalmol Vis Sci 44: 403-408, 2003.

29. Haas TL: Endothelial cell regulation of matrix metalloproteinases. Can J Physiol Pharmacol 83: 1-7, 2005.

30. Moses MA: The regulation of neovascularization of matrix metalloproteinases and their inhibitors. Stem Cells 15: S180-S189, 1997.

31. Jia Y, Liu M, Cao L, et al: Recombinant human endostatin, Endostar, enhances the effects of chemo-radiotherapy in a mouse cervical cancer xenograft model. Eur J Gynaecol Oncol 32: 316-324, 2011.

32. Zhang L, Ge W, Hu K, et al: Endostar down-regulates HIF-1 and VEGF expression and enhances the radioresponse to human lung adenocarcinoma cancer cells. Mol Biol Rep 39: 89-95, 2012. 